\title{
Detection of a subglacial lake in Glacier de Tête Rousse (Mont Blanc area, France)
}

\author{
Christian VINCENT, ${ }^{1}$ Marc DESCLOITRES, ${ }^{2}$ Stéphane GARAMBOIS, ${ }^{3}$ \\ Anatoly LEGCHENKO, ${ }^{2}$ Hélène GUYARD, ${ }^{2}$ Adrien GILBERT ${ }^{1}$ \\ ${ }^{1}$ Laboratoire de Glaciologie et Géophysique de l'Environnement, CNRS/Université Joseph Fourier, Grenoble, France \\ E-mail: christian.vincent@ujf-grenoble.fr \\ ${ }^{2}$ Laboratoire d'Étude des Transferts en Hydrologie et Environnement (LTHE), CNRS/IRD/INPG/Université Joseph Fourier, \\ Grenoble, France \\ ${ }^{3}$ Institut des Sciences de la Terre (ISTerre), CNRS/Université Joseph Fourier, Grenoble, France
}

\begin{abstract}
The processes that form intraglacial lakes are poorly understood because of the difficulty in detecting and assessing such hidden lakes. Extensive geophysical surveys were performed between 2007 and 2010 in order to reassess the risk of an outburst flood from Glacier de Tête Rousse, French Alps, where outburst flooding from an intraglacial lake caused 175 fatalities in 1892. Our geophysical survey combined ground-penetrating radar measurements and nuclear magnetic resonance imaging. We found a subglacial water-filled reservoir with a volume of $55000 \mathrm{~m}^{3}$. Artesian outpourings occurred when the subglacial cavity was reached by two borehole drillings, indicating that the hydrostatic water pressure exceeded the ice pressure at the bottom of the cavity. On the basis of these geophysical and glaciological findings, we warned the public authorities in July 2010 of the risk facing the $\mathbf{3 0 0 0}$ inhabitants downstream of the glacier. The subglacial reservoir was drained artificially. This example demonstrates how geophysical surveys can be used to detect this type of hazard when it is suspected, in particular when no hydraulic outlet from the snout exists. Numerous ice temperature measurements have shown that the tongue of this glacier is cold-based. This thermal regime could explain the accumulation of water in this glacier.
\end{abstract}

\section{INTRODUCTION}

A glacial outburst flood, sometimes referred to by the Icelandic term 'jökulhlaup', is a sudden release of water from a proglacial, supraglacial, englacial or subglacial lake. It can lead to extreme discharge events that can have catastrophic consequences in densely populated mountainous areas (e.g. Haeberli and others, 1989). Proglacial and supraglacial lakes which are visible from the surface can be recognized at an early stage of their formation. Many studies have been devoted to this kind of lake and in some cases technical measures have been taken to mitigate the potential hazards (e.g. Vallon, 1989; Haeberli and others, 2001, 2002; Mortara and Mercalli, 2002; Vincent and others, 2010a; Werder and others, 2010). Conversely, englacial and subglacial lakes represent intraglacial water reservoirs that are not visible from the surface and cannot be monitored by classical topographic and bathymetric measurements. Such water reservoirs have been studied mainly in Icelandic glaciers but can occur in many regions of the world (Mathews, 1964; Haeberli, 1983; Björnsson, 1992, 2010; Fountain and Walder, 1998; Roberts, 2005). In Iceland, these reservoirs are caused by meltwater produced by subglacial volcanic warming (Björnsson, 2003). In other regions, the origin of these cavities that can result in devastating outburst floods remains unclear (Haeberli, 1983; Walder and Driedger, 1995). The processes that form these intraglacial lakes are poorly understood because of the difficulty in detecting and monitoring such hidden lakes.

The deadliest outburst flood from an intraglacial cavity occurred in the French Alps on Glacier de Tête Rousse. During the night of 11 July 1892, the town of Saint-GervaisLe Fayet, $12 \mathrm{~km}$ from Chamonix (Mont Blanc area), was devastated by flooding that caused 175 fatalities. Following the disaster, two tunnels were drilled through the rock and ice to prevent new outburst floods (Fig. 1). The tunnel which was completed in 1904 has been maintained until now and was supposed to prevent water accumulation close to the bedrock of the glacier (Vincent and others, 2010b). However, over the last 106 years, no water has drained through this tunnel. The need to maintain the tunnel is therefore open to question.

Between 2007 and 2010, extensive glaciological and geophysical surveys were performed to check the potential existence of a subglacial water cavity and determine whether it could cause another outburst flood. Against all expectations, our study revealed a subglacial lake. This paper summarizes the results of this study, which led to the artificial drainage of this subglacial lake. The possible hydromechanical opening of drainage pathways leading to the formation of the intraglacial cavity is beyond the scope of this paper. The overall mechanism that leads to such subglacial cavities remains unclear.

The goal of this paper is to: (1) present the methods used to detect this new subglacial lake; (2) present the geophysical results which led to risk assessment, the issuing of a warning to the public authorities and the decision to drain the subglacial cavity artificially; and (3) analyse the thermal regime which could partly explain the accumulation of water in this glacier.

To our knowledge this is the first time that a subglacial water-filled reservoir has been detected from geophysical survey of an alpine glacier.

\section{METHODS}

Different geophysical surveys have been carried out on Glacier de Tête Rousse. In 2007, ground-penetrating radar 


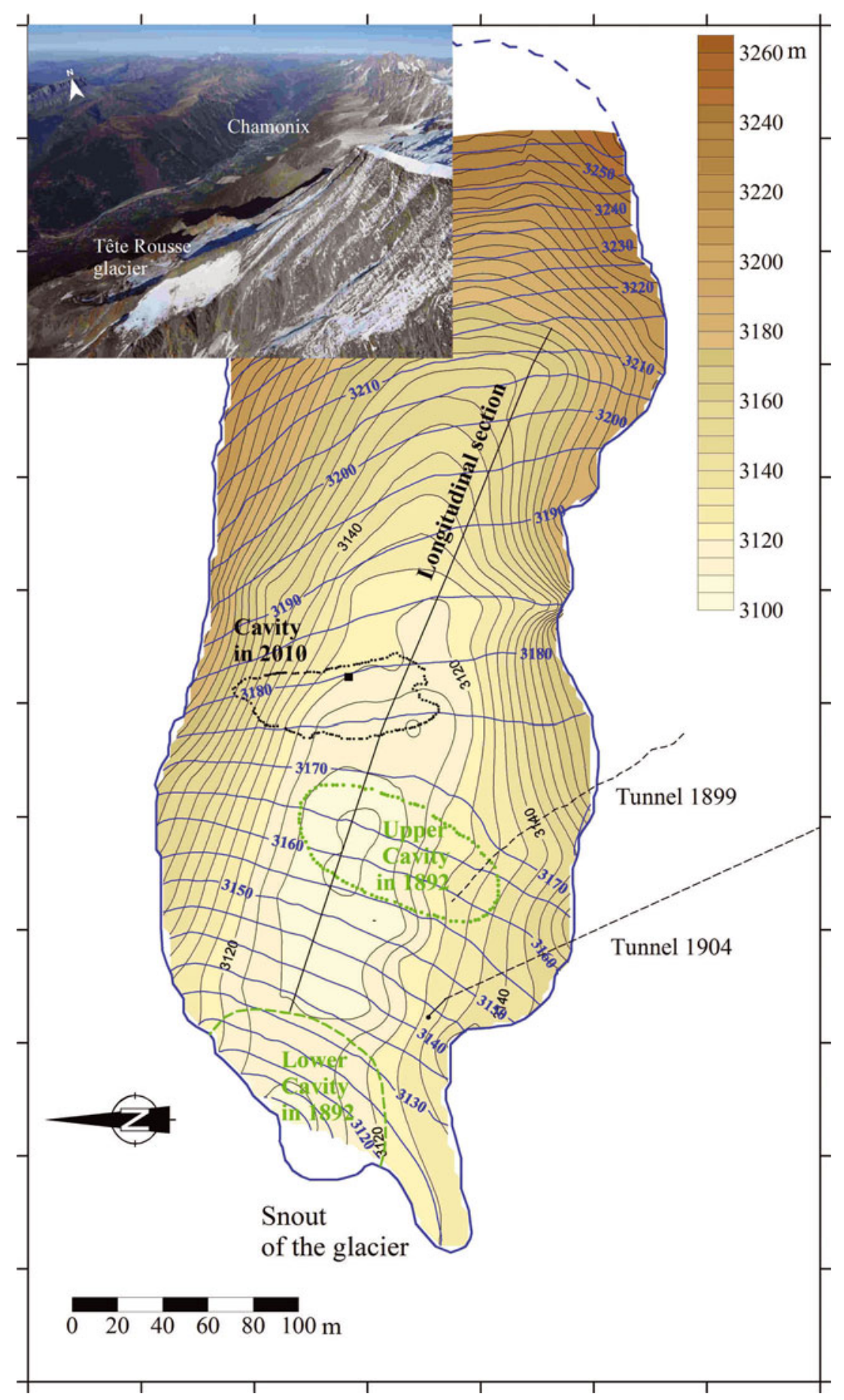

Fig. 1. Map of surface (blue contours) and bedrock topography (shown by black contours and the colour scale) in 2007 (Vincent and others, 2010b). The locations of the upper and lower cavities (green dashed line) resulting in the outburst flood in 1892 are shown along with the location of the cavity mapped in 2010 (black dashed line) from sonar measurements (from this paper) performed in a borehole (black square). The black line is the longitudinal section shown in Figure 4. Photograph by P. Tournaire.

(GPR) measurements, initially performed to obtain the bedrock topography, led us to suspect the presence of a water reservoir within the glacier. In 2009, we used surface nuclear magnetic resonance (SNMR) imaging to determine the volume of water contained in this glacier. Finally, boreholes drilled in 2010 enabled us to confirm the presence of a subglacial water cavity.

\subsection{Radar measurements}

GPR has been used successfully on various temperate glaciers, mainly to map bedrock geometry (Arcone and others, 1995) or to study the distribution of water in polythermal glaciers (e.g. Murray and others, 1997; Moran and others, 2000; Irvine-Fynn and others, 2006; Barrett and others, 2008). In particular, recent GPR surveys have been used to delineate cold/warm transition zones from backpropagation of GPR scatters (Björnsson and others, 1996; Murray and others, 2000; Pettersson and others, 2004; Barrett and others, 2008).

In October 2007, GPR measurements were carried out using a $250 \mathrm{MHz}$ shielded antenna (antenna spacing of $36 \mathrm{~cm}$ ) connected to a RAMAC/GPR system (MALA 


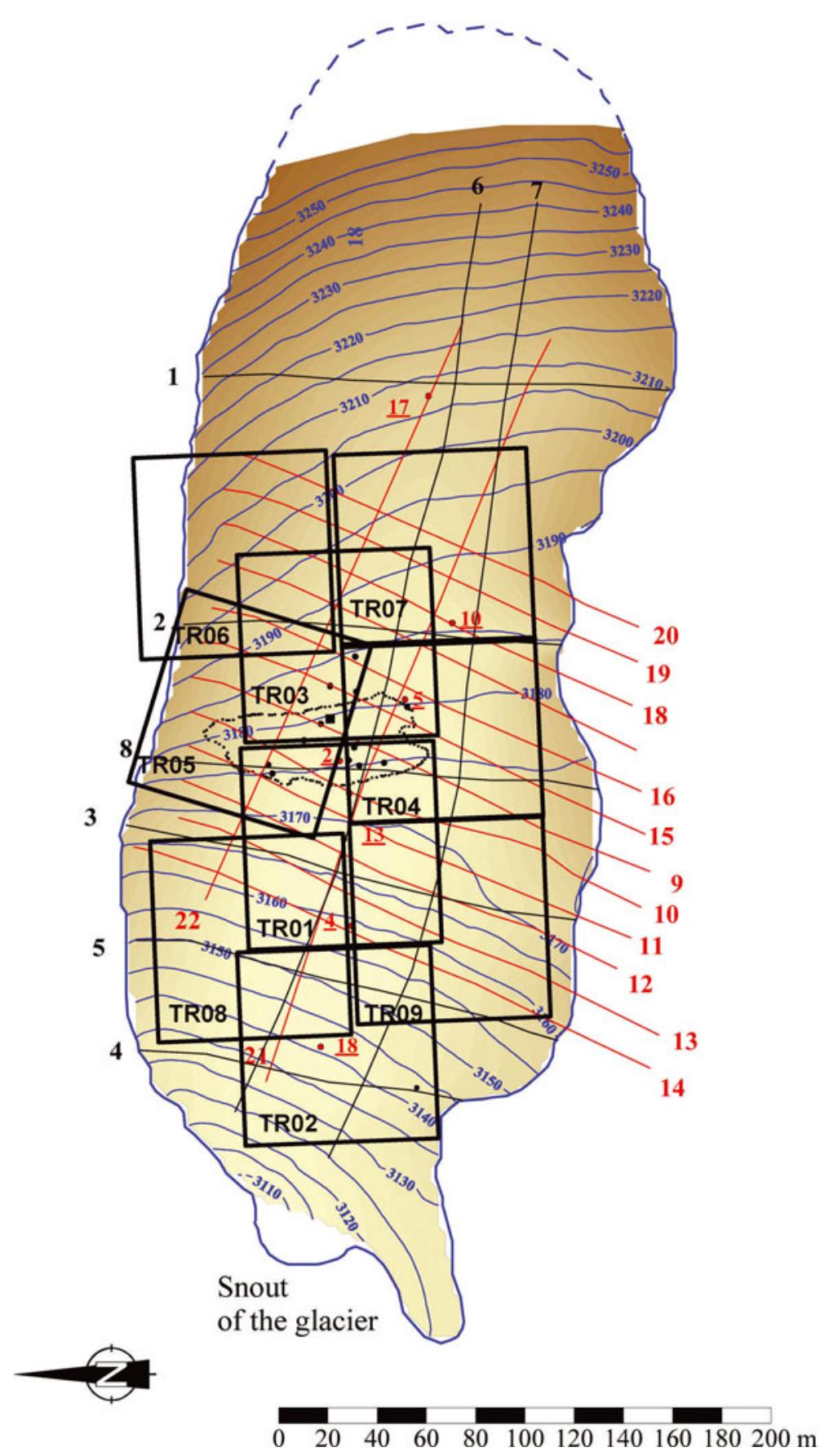

Fig. 2. Map of the surface topography of Glacier de Tête Rousse with radar profiles and SNMR loops. Radar measurements were carried out along eight profiles in 2007 using a $250 \mathrm{MHz}$ antenna (black lines) and along 14 profiles in $2010 \mathrm{using}$ a $100 \mathrm{MHz}$ antenna (red lines). The boreholes are plotted as dots, the red dots corresponding to holes equipped with thermistors (underlined numbers). SNMR loops are shown as squares outlined in black. The location of the cavity detected in 2010 (black dashed line) from sonar measurements performed in a borehole (solid black square) is shown. The colour scale and contours are similar to Figure 1. The exact extension of the glacier is unknown given that the glacier is partly debris-covered on the edges.

Geosciences) in order to determine the bedrock topography of Glacier de Tête Rousse. From the available GPR antennas $(50,100,250$ and $500 \mathrm{MHz})$, a shielded $250 \mathrm{MHz}$ antenna was chosen because of preliminary (and false) borehole information indicating that the ice thickness was $<40 \mathrm{~m}$ (Vincent and others, 2010b). In this context, it was thought that $250 \mathrm{MHz}$ GPR signals would image the ice/bedrock interface successfully while exhibiting a vertical resolution of $<20 \mathrm{~cm}$ (a quarter of a wavelength). The other advantages of this antenna are of a practical nature and lead to faster acquisition. Measurements on six cross sections (separated by $>30 \mathrm{~m}$ ) and two longitudinal sections with a spacing of
$50 \mathrm{~cm}$ between measurements along a given section (Fig. 2) were performed during the first GPR campaign in 2007. This antenna proved to be satisfactory, providing high vertical resolution images of the glacier (wavelength of $67.2 \mathrm{~cm}$ for a wave propagation velocity of $16.8 \mathrm{~cm} \mathrm{~ns}^{-1}$ within the glacier), with waves penetrating deep enough to reach the glacier/bedrock interface (Vincent and others, 2010b). GPR images showed large anomalies (mainly large scattering), especially in the centre and deepest part of the glacier, making it impossible to follow the continuity of the glacier/ bedrock interface in this limited part of the glacier despite use of the migration process. 

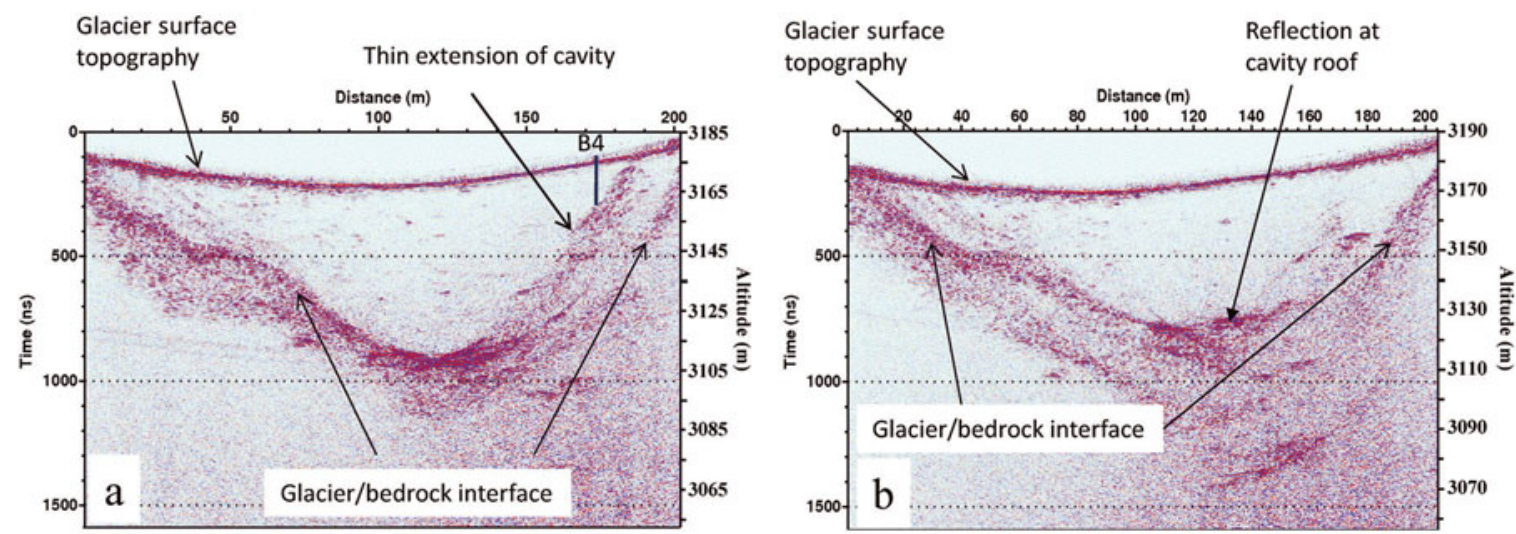

Fig. 3. South-north GPR data displayed in the two-way travel time domain using a $100 \mathrm{MHz}$ antenna on cross sections (a) 10 and (b) 9 after migration and static corrections (the north direction is to the right). On the right axis an altitude scale is proposed after time-to-depth conversion was applied. Data from borehole B4 are shown.

Complementary studies were conducted in May 2010 to better characterize these large heterogeneities, including denser GPR profiles (12 cross sections separated by $15 \mathrm{~m}$ and two long longitudinal profiles, with $40 \mathrm{~cm}$ between measurements) and four common midpoint (CMP) surveys. GPR data were acquired using $100 \mathrm{MHz}$ rough terrain antennas (RTA) from MALA Geosciences, with an all in-line design that improves performance for deeper penetration. Transverse magnetic acquisition mode was used, different from the more classical transverse electric (TE) acquisition mode in terms of reflectivity sensitivity to offset and in terms of radiation pattern. In this mode, the electric field is more focused under the antenna compared with TE mode and the energy strongly decreases when the emission angle is $>30^{\circ}$ (Deparis and Garambois, 2009). In our case, this property should limit potential three-dimensional (3-D) effects and out-of-plane reflections which may occur in this highly heterogeneous medium. Antennas with a frequency of $100 \mathrm{MHz}$ were chosen to increase penetration depth, necessary given the large observed thickness of the glacier and the potential presence of water, both of which attenuate GPR signals. Here, vertical resolution is about $37 \mathrm{~cm}$ when considering Rayleigh's criteria.

The CMP surveys indicated an electromagnetic velocity of $16.8 \mathrm{~cm} \mathrm{~ns}^{-1}$ within the relatively homogeneous first $40 \mathrm{~m}$ of the glacier and a more complex velocity profile at greater depth. Raw GPR data processing included: (1) suppressing direct currents; (2) filtering using a $20-350 \mathrm{MHz}$ frequency passband; (3) static corrections with a velocity of $16.8 \mathrm{~cm} \mathrm{~ns}^{-1}$; (4) amplification of late arrivals with an exponential gain; and (5) two-dimensional (2-D) Stolt migration with a constant velocity of $16.8 \mathrm{~cm} \mathrm{~ns}^{-1}$. For all profiles, the 2-D migration process appears to focus scattering energy and relocate dipping reflected events (Fig. 3) in a satisfactory manner. Data are presented as a function of the two-way travel time, as we suspect large velocity changes within the glacier and difficult time-to-depth conversions.

\subsection{SNMR imaging measurements}

We performed geophysical measurements in 2009 using the SNMR imaging method. Since 1982, this method has been used in groundwater exploration to investigate one-dimensional (1-D) (Legchenko and Valla, 2002) and 2-D watersaturated formations (Boucher and others, 2006; Girard and others, 2007; Legchenko and others, 2008; Hertrich and others, 2009). The 1-D mathematical model of the method has been verified by measuring magnetic resonance signals from bulk water in a lake (Schirov and others, 1991; MüllerPetke and others, 2011). The magnetic resonance measurements on samples have also been used to investigate frozen soils and ice (Callaghan and others, 1999; Kleinberg and Griffin, 2005). Selective sensitivity to groundwater is the main advantage of SNMR compared with other geophysical methods (see Appendix). The SNMR instrument is designed to measure magnetic resonance signals generated by liquid water in porous media. Such signals have a relaxation time exceeding $40 \mathrm{~ms}$. Because cold ice is a solid material, it produces much shorter signals that cannot be detected by SNMR.

The SNMR field set-up consists of a wire loop laid out on the ground. The depth of investigation depends on the loop size, electrical conductivity of the subsurface, magnitude of the geomagnetic field and signal-to-noise ratio and varies between 40 and $120 \mathrm{~m}$ (Legchenko and others, 1997).

To improve the accuracy of the interpretation in a heterogeneous environment, Legchenko and others (2011) developed a new 3-D methodology and corresponding interpretation software (3-D-SNMR). The 3-D imaging consists of measuring the magnetic resonance signal independently in each loop while varying the current in the loop. All individual soundings are incorporated into a dataset for 3-D inversion. The method can be used to investigate subsurface structures that contain more than a few thousand cubic metres of water. The performance of the method depends on the position of the target volume relative to the SNMR loop, the amount of subsurface water and the magnitude of ambient electromagnetic noise. Consequently, the sensitivity and resolution of the method should be assessed for each survey with respect to these site-specific conditions.

In September 2009, nine SNMR measurements were carried out in Glacier de Tête Rousse using an $80 \mathrm{~m} \times 80 \mathrm{~m}$ square loop (Fig. 2). Owing to field conditions, the shape of SNMR loops TR05 and TR06 was deformed and consequently the magnetic field was computed with greater error than for a normal quasi-horizontal position of the loop. However, in the northern part of the investigated area, the glacier is bordered by steep bedrock that contains neither ice nor alluvium deposit. Thus, existence of water in this area is highly improbable. Hence, inaccuracy in the mathematical model caused by the shape of the loops in 


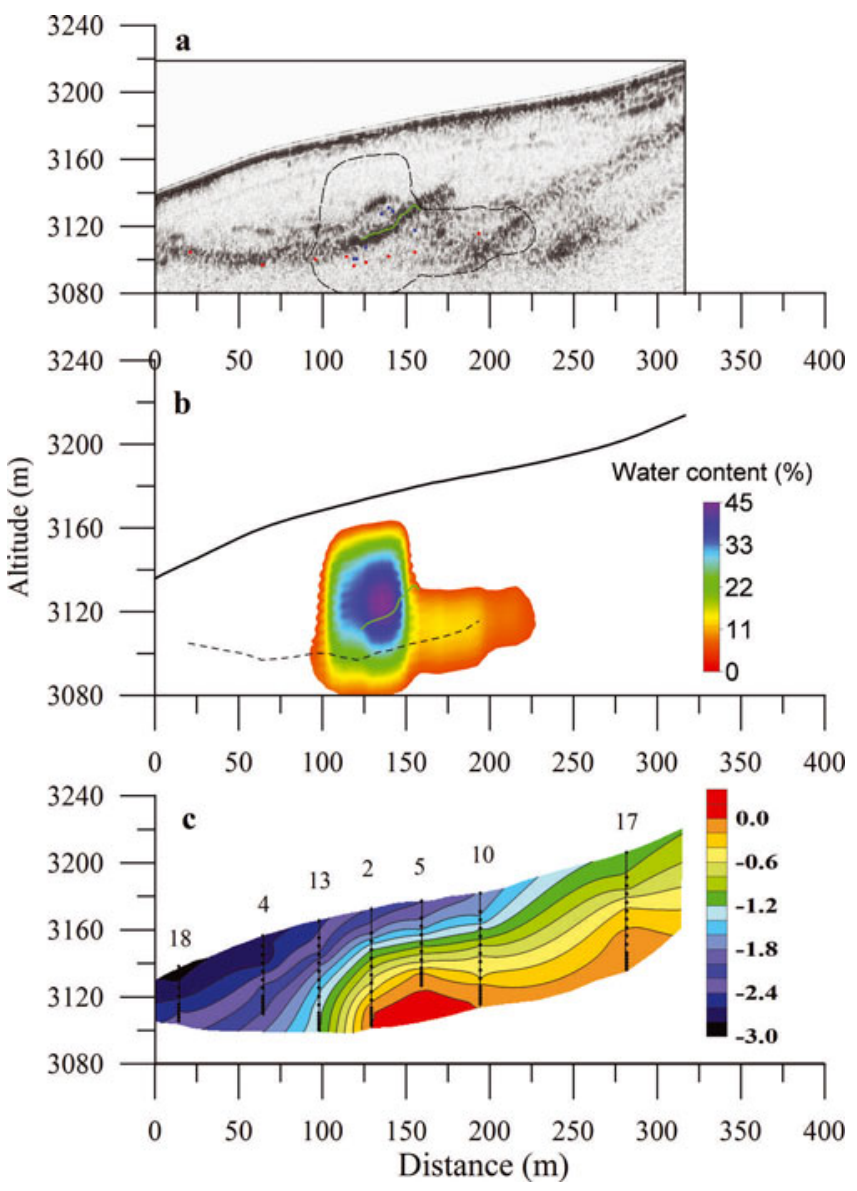

Fig. 4. Longitudinal section of the glacier (shown in Fig. 1). (a) Depth radar image derived after applying static correction and migration processes to the data (with an electromagnetic wave propagation velocity in ice of $16.8 \mathrm{~cm} \mathrm{~ns}^{-1}$ ). The red dots correspond to the bottoms of the boreholes (note the out-of-plane offset of the boreholes from the profile line shown in Fig. 1). The blue dots correspond to the cavity roof obtained from boreholes. The green line shows the roof of the cavity obtained from sonar measurements. The black dashed line corresponds to the outline of the water distribution drawn in (b). (b) Distribution of the modelled water content within the glacier along the longitudinal section shown in Figure 1 and derived from 3-D-SNMR inversion. The dashed line corresponds to bedrock. (c) Ice temperature. Data have been interpolated from measurements (black dots) performed in boreholes.

this part of the glacier is unlikely to influence the accuracy of the interpretation.

The water distribution inside the glacier was derived from 3-D inversion of experimental data (Legchenko and others, 2011). Inversion was carried out using the Tikhonov regularization method which provides a smooth solution. The main advantage of this method is that the solution corresponding to the minimum of Tikhonov's function is unique and stable.

The duration of each sounding was about 6 hours. Moreover, 1 hour was required to install the loop. Therefore, only one sounding per day was possible. For our numerical study and inversion, we used a Dell Precision M6500 portable computer (Intel ${ }^{\mathbb{R}}$ Core $^{\mathrm{TM}}$ i7 920X CPU, $2 \mathrm{GHz}$, 7.92 GB RAM). With this computer, one 3-D inversion of a nine-loop dataset takes about $15 \mathrm{~min}$. Usually five to six inversions are sufficient to optimize Tikhonov's function. Inversion was done with 6000 iterations. The fitting error rmse is $7.7 \mathrm{nV}$ and the maximum signal $156 \mathrm{nV}$.

\subsection{Boreholes and ice temperature measurements}

In July 2010, 20 boreholes were drilled using hot water to: (1) determine the exact location of the cavity; (2) measure the water level in each borehole; and (3) monitor the ice temperature using thermistors (Fig. 1). The depth of the boreholes varied from 34 to $76 \mathrm{~m}$. Five of the drilling holes were obstructed by rocks in the ice and did not reach bedrock as shown by new holes drilled a few metres away. The water levels were monitored in two boreholes using an OTT Orpheus groundwater data logger. In addition, a single contact gauge was used to measure the water level at other boreholes. Chains of thermistors with $0.1^{\circ} \mathrm{C}$ accuracy were installed in seven of the deep boreholes (Fig. 2). They were spaced every $2 \mathrm{~m}$ from bedrock up to $10 \mathrm{~m}$ above bedrock and then every $5 \mathrm{~m}$ up to the surface. The temperatures were measured five times between July and September 2010. Little change was observed between the last two measurements, 19 days apart $\left( \pm 0.1^{\circ} \mathrm{C}\right)$, indicating that a thermal equilibrium had been reached.

\subsection{Sonar measurements}

Sonar measurements were carried out in one borehole (black square in Fig. 1) in August 2010 to determine the geometry of the cavity. These measurements were performed using a sonar instrument designed by the Flodim company. Thanks to a rotating and tilting head bearing acoustic transducers, the instrument records the position of acoustic reflections in any direction in the filled part of the cavity. The cavity was surveyed through 66 horizontal and tilted sections. The measurements are orientated thanks to an electronic compass. In total, 12000 points were measured in the filled cavity.

\section{RESULTS}

\subsection{Radar data analysis}

From radar measurements, we detected a large number of out-of-plane reflections at greater depths. These reflections are related to a strong deep large 3-D reflector within the glacier, which creates out-of-place scattering. Three migrated images corresponding to cross sections 9 and 10 and the longitudinal cross section 21 are presented in Figures 3 and 4, respectively. The glacier/bedrock interface map was deduced from migrated data obtained in the 2007 GPR campaign and interpolated (Fig. 1).

Comparing the two migrated profiles presented in Figure 3, we note a large difference between the two images, although they are separated by only $15-20 \mathrm{~m}$. On cross section 10, the glacier appears to be relatively homogeneous with a well-defined continuous glacier/bedrock interface. Note the larger reflectivity at the centre, which may be associated with the presence of the very thin water-filled cavity. On the northern flank, numerous scattering events have been correctly focused with the migration process and join to form a relatively continuous rough interface dipping from the surface to the centre of the glacier. We interpreted this rough interface as an extension of the cavity towards the surface of the glacier. This interpretation was supported by observations made during the drilling of a borehole (B4) on the northern flank of the glacier, which intersected a thin water-filled cavity at $9 \mathrm{~m}$ depth (Fig. 3). In addition, sonar data acquired within the cavity to reconstruct its geometry confirmed this extension. 
On the other hand, cross section 9 shows a strong reflector located in the middle of the cross section at $\sim 45 \mathrm{~m}$ depth, which is absent $20 \mathrm{~m}$ downstream (i.e. in cross section 10). This reflection seemed to be generated by the roof of the water-filled cavity, as subsequently confirmed by the boreholes. Below this reflector, there is an apparent deepening of the glacier/bedrock interface due to 3-D effects. Below the cavity roof, the presence of the water-filled cavity dramatically attenuates the GPR signals and creates a very large velocity drop that prevents imaging of the glacier/bedrock interface. The deepest reflected event observed at about $1300 \mathrm{~ns}$ may be related to out-of-plane reflections (3-D effects) or to a deep and large discontinuity within the bedrock layer. In addition, the electromagnetic waves were strongly attenuated in this area. All these features result in a large spatial discontinuity of the glacier/bedrock interface.

Cross section 21 displayed in Figure 4a is more complex to interpret and presents a lack of continuity in terms of the deeper reflectors, which disappear in the deepest part of the glacier. It clearly shows the presence of a large interface between 110 (at $\sim 75 \mathrm{~m}$ depth) and $160 \mathrm{~m}$ (at $\sim 45 \mathrm{~m}$ depth), which must be the signature of the glacier/water interface. Note that there is a good agreement between the cavity roof obtained from sonar data and the GPR reflections. Note also that the apparent deepening of the dipping of the glacier/ bedrock interface between 160 and $230 \mathrm{~m}$ may be related to a velocity pushdown due to the presence of a small quantity of water at the glacier/bedrock interface. In this case, the velocity of electromagnetic waves decreases dramatically.

All these observations led us to suspect the presence of a subglacial water reservoir extending $50 \mathrm{~m}$ in the longitudinal direction (east-west) and $45 \mathrm{~m}$ in the transverse direction (south-north). Based on GPR data, the cavity appears to be located deeper than $40 \mathrm{~m}$ and reaches bedrock.

\subsection{SNMR data analysis}

The water distribution inside the glacier was derived from 3-D inversion of experimental data (Legchenko and others, 2011). The main subglacial reservoir was located by SNMR to be in the central part of the glacier between 30 and $70 \mathrm{~m}$ depth. Comparison showed that 3-D-SNMR results were consistent with the anomaly detected from radar measurements (Fig. 4). The maximum water content derived from SNMR results (Figs 5 and 6 ) was $\sim 45 \%$. This seems to conflict with the value of $100 \%$ expected in the subglacial reservoir. The discrepancy can be explained by the limited resolution of the SNMR method. Indeed, the water reservoir in the glacier is composed of caverns and channels of different size and length, and such a complex shape cannot be resolved accurately with the inversion. Thus, the SNMR solution provides an average water content in the investigated volume composed of water and ice.

We studied the sensitivity and resolution of the method numerically, using synthetic signals computed for different 3-D target water volumes located in cold ice (Legchenko and others, 2011). For modelling, we used a square loop with an $80 \mathrm{~m}$ side, a Larmor frequency of $2005 \mathrm{~Hz}$, a geomagnetic field inclination of $62^{\circ} \mathrm{N}$, a subsurface resistivity of $100 \Omega \mathrm{m}$ and a maximum pulse moment of $12000 \mathrm{Ams}$. In order to estimate the uncertainty in target location, we used an inversion of synthetic data for different model targets. Inversion was carried out by meshing the subsurface with equal-sized cells. We performed inversions with different cell sizes: $5 \mathrm{~m} \times 5 \mathrm{~m} \times 5 \mathrm{~m}, 10 \mathrm{~m} \times 10 \mathrm{~m} \times 5 \mathrm{~m}, 20 \mathrm{~m} \times 20 \mathrm{~m}$

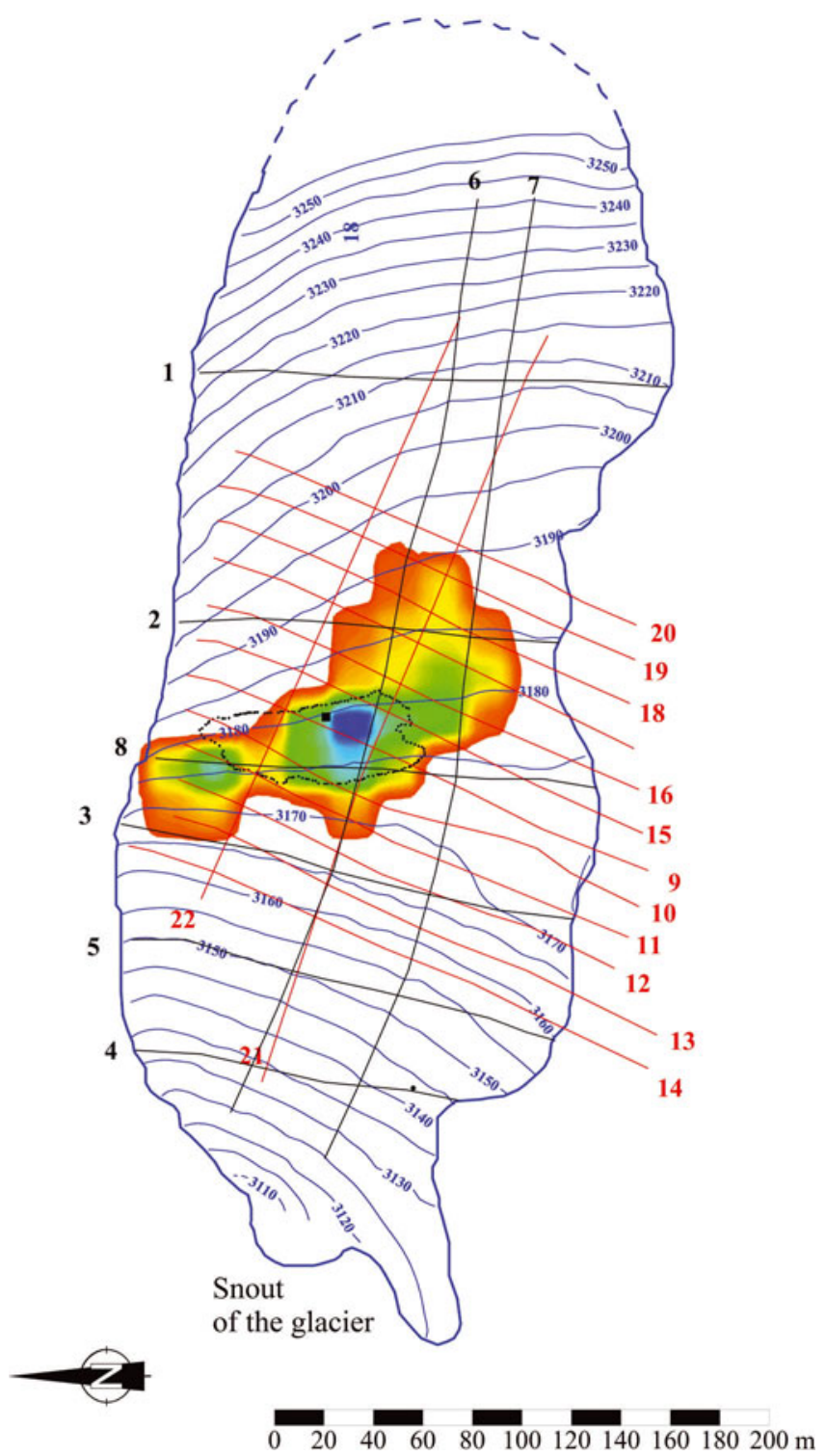

Fig. 5. Horizontal slice of the modelled water content at $56 \mathrm{~m}$ depth derived from 3-D inversion of SNMR data. Contours of the surface are shown in blue. Radar measurements on profiles are shown in black and red (see Fig. 2). The colour scale is the same as in Figure $4 b$.

$\times 5 \mathrm{~m}, 40 \mathrm{~m} \times 40 \mathrm{~m} \times 5 \mathrm{~m}$. We did not change the cell size in the $Z$ direction (depth) because the vertical resolution of the SNMR method is known from a previous study (Legchenko and Shushakov, 1998). Analysis of the results show only small differences in the solution shape when using cells $20 \mathrm{~m} \times 20 \mathrm{~m} \times 5 \mathrm{~m}$ or smaller. However, the difference was more pronounced between solutions obtained with $20 \mathrm{~m}$ $\times 20 \mathrm{~m} \times 5 \mathrm{~m}$ and $40 \mathrm{~m} \times 40 \mathrm{~m} \times 5 \mathrm{~m}$ cells. We interpreted this difference as an indication that different areas within $40 \mathrm{~m} \times 40 \mathrm{~m} \times 5 \mathrm{~m}$ cells produce signals that can be distinguished by the inversion. From these results, we conclude that the position of the target can be found with an uncertainty of one $20 \mathrm{~m} \times 20 \mathrm{~m} \times 5 \mathrm{~m}$ cell. This approach provided an approximate estimation of the uncertainty as $\pm 20 \mathrm{~m}$, which was later confirmed by boreholes.

Legchenko and others (2011) have shown that the sensitivity of the SNMR method is not homogeneous within the loop and the resolution provided by the smooth inversion is not sufficient to estimate the volume of water 

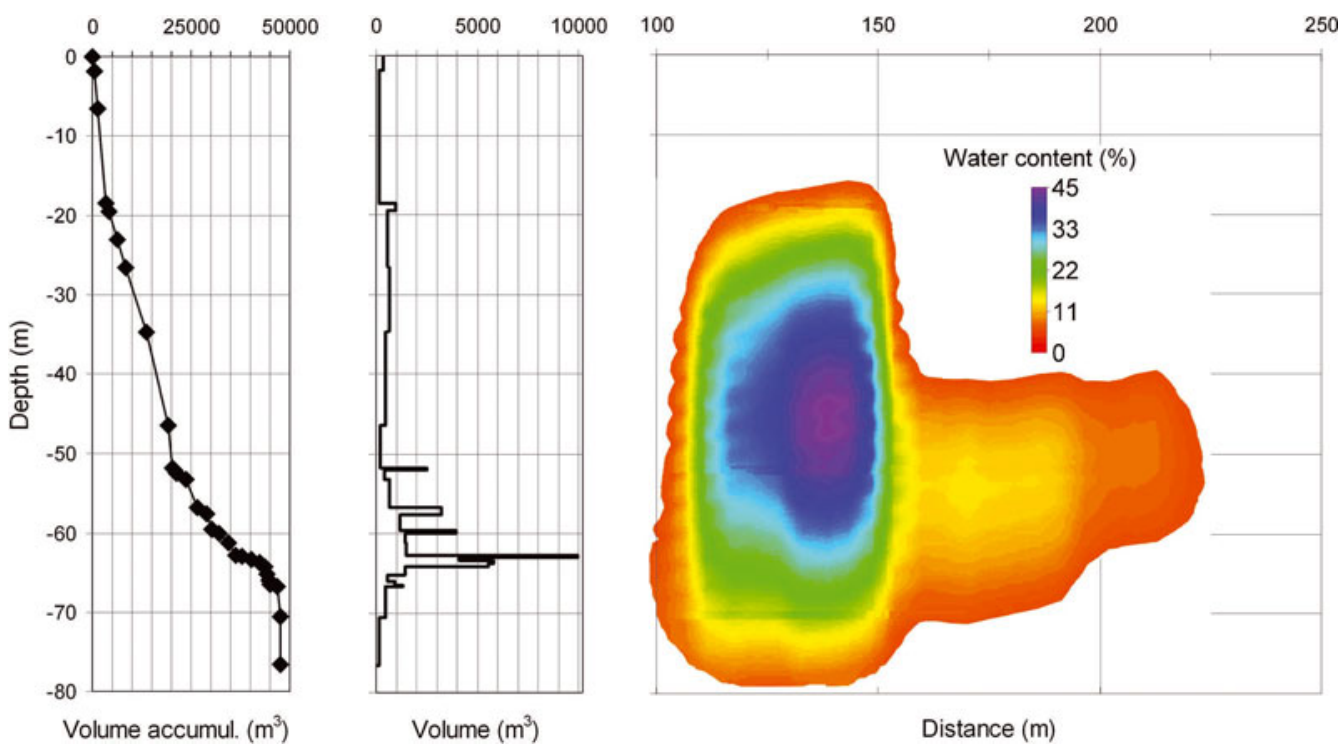

Fig. 6. (a) Accumulated volume of water extracted from Glacier de Tête Rousse as a function of the water level in the cavity; (b) volume of water extracted from different depth intervals; and (c) SNMR cross section of the modelled water content along radar cross section 21 (Figs 1 and 2).

from the inversion results. Thus, to estimate the volume of water in the subsurface, we used a forward modelling procedure that makes it possible to apply different constraints on the solution. To build a box model, we used the 3 -D image of the cavern obtained with the smooth inversion. It was found that a 3-box model fits measured data with approximately equal accuracy. Slightly different 3-box models represent different equivalent solutions.

For hazard prevention, knowledge of the minimum volume of accumulated water is essential. We therefore selected four 3-box models (equivalent solutions) taking into account the sensitivity map of the SNMR loop. For that, in each model, boxes were located in the minimum sensitivity area of the loop. Thus, our four models provide the minimum volume of accumulated water that fits measured signals.

Modelling was carried out for each of the four 3-box models. We followed the discrepancy principle introduced by Morozov (1966), which assumes that for erroneous data all solutions that have a residual error smaller than the experimental error are acceptable. We varied the water content and the height ( $Z$ coordinate) of each box (the $X$ and $Y$ coordinates of each box were not changed, in order to keep the boxes in the minimum sensitivity areas of the SNMR loop) so that the data were fitted with an error equal to the experimental noise. Two cases were studied: the minimum possible signal and the maximum possible signal. Such a procedure provided the minimum and maximum volume of water for the geometry corresponding to the minimum possible volume of water.

Modelling with our four 3-box models suggested that we cannot have $<45000 \mathrm{~m}^{3}$ and we should not have $>65000 \mathrm{~m}^{3}$ of accumulated water. These results provide a value of $55000 \pm 10000 \mathrm{~m}^{3}$ which approximately corresponds to an uncertainty of $\pm 20 \%$.

SNMR measurements were also carried out during pumping in September 2010. Four SNMR measurements (loop positions 1, 3, 7 and 8) were performed between 26 and 29 September 2010. For these measurements, the cavern contained less water and thus had a smaller signalto-noise ratio. Consequently, the resolution of SNMR imaging was worse in comparison with the full cavern measurements. However, the position of the cavern was already known and we were looking for the volume of remaining water. To estimate the volume, we used the forward modelling procedure described above. However, we constrained the model using the water level and bedrock location known from boreholes. The position of the cavern was also known approximately from previous SNMR imaging and from drillings. Under these conditions, our modelling revealed that observed signals can be explained with the water volume varying between 17000 and $25000 \mathrm{~m}^{3}$, which yields a value of $21000 \pm 4000 \mathrm{~m}^{3}$. Therefore, our uncertainty was estimated to be about $\pm 20 \%$.

\subsection{Water level in drilling holes}

GPR and SNMR measurements enabled us to choose the locations of the boreholes drilled to reach the presumed subglacial cavity. Indeed, we found a subglacial water reservoir at the bottom of six boreholes. One borehole showed a $29 \mathrm{~m}$ high cavity with its bottom on bedrock (black square in Fig. 2). A video camera was introduced in some boreholes to inspect the cavity. The walls of the boreholes were clearly visible from the glacier surface to the roof of the subglacial cavity. In the subglacial water reservoir, the image was black. At the bottom of the boreholes, bedrock was easily recognized. Sonar measurements were performed in one borehole to determine the geometry of the cavity. However, owing to the complex shape of the cavity, it was not possible to obtain an entire 3-D model of the cavity from these sonar measurements. A large part of the cavity could not be detected from sonar measurements performed in one borehole because the sonar measurements enable direct measurements only from one vertical line. Numerous sonar measurements in different boreholes would have been required to investigate the entire cavity. A 3-D view of the filled cavity obtained from the sonar measurements is given in Figure 7. The volume obtained from these measurements was assessed at $24500 \mathrm{~m}^{3}$, far less than the volume of $55000 \mathrm{~m}^{3}$ found with the SNMR method. Although the radar measurements were not performed exactly at the drilling 


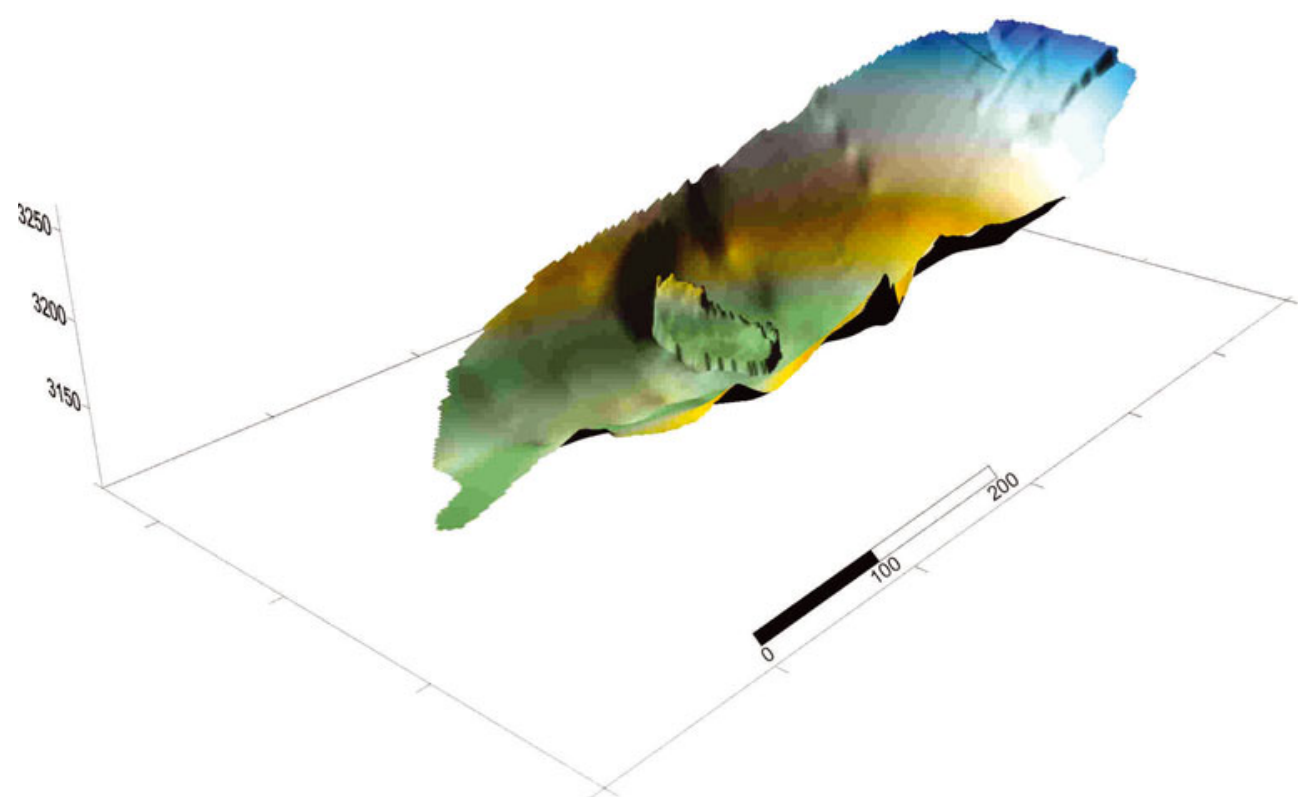

Fig. 7. 3-D view of the glacier bedrock with the subglacial cavity inferred from sonar measurements. Only a part of the subglacial cavity is visible from sonar measurements.

locations, we were able to conclude that the anomaly detected from radar measurements corresponded to the roof of the cavity identified by the boreholes and sonar measurements (Fig. 4a). We found similar water levels in eight boreholes $(3172.8 \pm 0.2 \mathrm{~m})$, indicating that these boreholes were probably connected. However, only identical changes in water level would prove the connection between the boreholes. Unfortunately, the observations were not long enough to observe changes in water levels. At two of these boreholes, artesian outpourings $10-20 \mathrm{~cm}$ higher than the glacier surface occurred when the subglacial cavity was reached, indicating that the hydrostatic pressure exceeded the ice overburden pressure at the bottom of the cavity.

\subsection{Thermal regime of the glacier}

The ice temperatures obtained from the chains of thermistors installed in the boreholes located on a longitudinal section show a striking feature (Figs 4 and 8). The basal ice is temperate or near-temperate in the first $10 \mathrm{~m}$ above bedrock for boreholes 17, 10, 5 and 2 located in the upper part of the glacier. Conversely, boreholes 13, 4 and 18 located on the tongue of the glacier show cold basal ice. The bottoms of boreholes 2 and 5 are clearly located in the subglacial water-filled cavity. The upper borehole 17 is very far from the subglacial cavity (Fig. 4c). However, the basal ice of this borehole is temperate or near-temperate in the first $20 \mathrm{~m}$ above bedrock. Moreover, we note a strong horizontal gradient in ice temperature measured in the first $40 \mathrm{~m}$ below the surface from the upper part to the lower part of the glacier. The possible cause of this horizontal gradient is discussed below. From Figure 8, an abrupt transition in temperature $\left(-1.4^{\circ} \mathrm{C}\right.$ at the bedrock and $-0.5^{\circ} \mathrm{C} 10 \mathrm{~m}$ below the surface) can be seen between boreholes 2 and 13 located $32 \mathrm{~m}$ apart. The boundary of the subglacial cavity is located precisely between these two boreholes. In addition, visual observations showed no subglacial water flowing from the snout. These results suggest that the cold ice frozen to the bedrock could explain the water storage in this area. This point is discussed below.

\section{DISCUSSION}

\subsection{Hazard analysis}

The results obtained in July 2010 following the GPR and SNMR measurements and the borehole drilling campaign forced us to make an immediate decision. The hazard was analysed urgently on the basis of the following data: (1) the volume of the water contained in the glacier was assessed at $55000 \mathrm{~m}^{3}$; (2) the boreholes and the SNMR and GPR measurements tended to show that this water was contained in a single subglacial cavity; and (3) the hydrostatic water pressure exceeded the ice pressure at the bottom of the

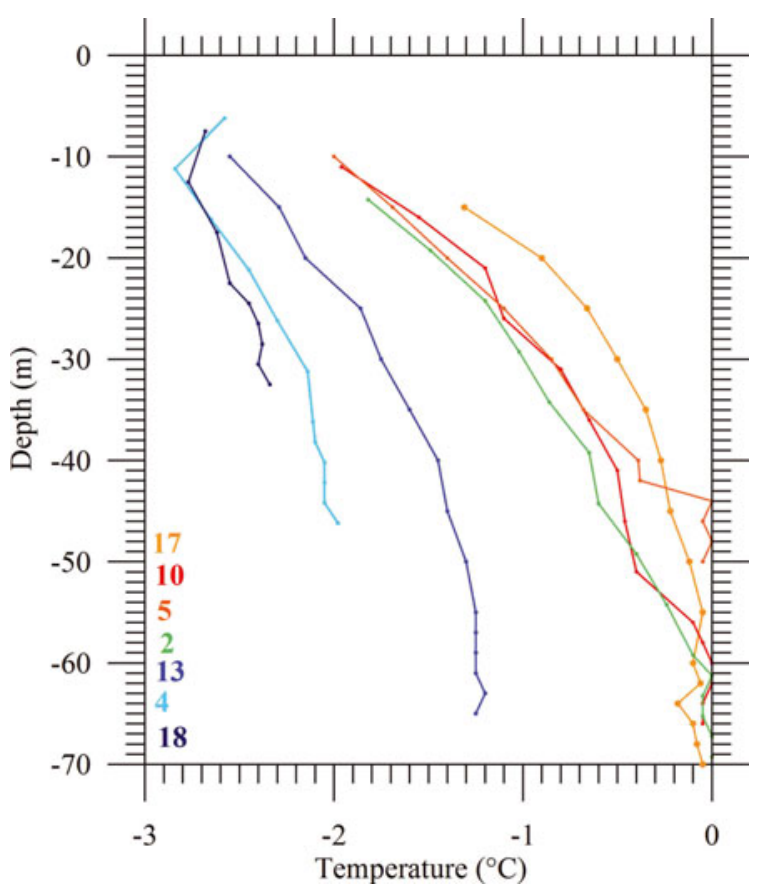

Fig. 8. Ice temperatures measured in the boreholes shown in Figure 2 after thermal equilibrium has been reached. 
cavity. The question was whether this subglacial cavity could cause an outburst flood and repeat the 1892 disaster.

It is commonly accepted that drainage of glacial lakes is initiated when the hydrostatic pressure at the seal is equal to the minimum hydraulic potential in the region damming the lake (e.g. Fountain and Walder, 1998; Roberts, 2005). Drainage can even occur before the conditions for ice dam flotation are met (Mathews, 1964; Björnsson, 1974, 1992; Clarke, 1982; Roberts, 2005). The conditions for ice dam flotation were met in Glacier de Tête Rousse because artesian outpourings were observed at two boreholes. This meant that we could expect that the water contained in Glacier de Tête Rousse would be released. Given that the mechanism triggering the opening of englacial conduits remains unclear (Van der Veen, 1998, 2007; Boon and Sharp, 2003), we could not exclude that the water would be released suddenly. Therefore, the release mechanism could result in sudden subglacial drainage (scenario 1) or in collapse of the terminus (scenario 2) (Sturm and Benson, 1985; Roberts, 2005; Sugiyama and others, 2008). The expected magnitude of the flood peak was crucial to the inhabitants of the downstream valley. Using the Clague-Mathews relation (Clague and Mathews, 1973), an outburst flood ensuing from scenario 1 could have reached a glacier-proximal $Q_{\max }$ of $\sim 1 / 1000$ of the total volume (Walder and Driedger, 1995), i.e. $65 \mathrm{~m}^{3} \mathrm{~s}^{-1}$ for Glacier de Tête Rousse. Fountain and Walder (1998) suggest that for a small glacier $\left(<1 \mathrm{~km}^{2}\right)$, an upper bound for discharge is $100 \mathrm{~m}^{3} \mathrm{~s}^{-1}$. The second scenario, which involves a collapse of the terminus similar to the phenomenon that produced the 1892 outburst flood, could have released the $55000 \mathrm{~m}^{3}$ of water instantaneously.

\subsection{Warning and mitigation measures}

The risk related to an outburst flood depends on numerous factors (e.g. Haeberli and others, 1989) including potential flood volume, outburst mechanisms, erosion and deposition processes, distance to human infrastructures, etc. It is not the intention here to analyse all aspects of the risk relative to a potential outburst flood of Glacier de Tête Rousse. In July 2010, the decision was made to take urgent measures based on the analogy with the 1892 event. The volume of water contained in Glacier de Tête Rousse in 1892 was about $100000 \mathrm{~m}^{3}$, similar to the volume of water measured in 2010. Owing to the steep slopes covered with moraines, the sudden emptying of the subglacial lake led to devastating debris flows, sweeping away everything in their path and carrying with them water, boulders, soil and mud. Given that a part of the tongue was torn out of the glacier, the total volume of ice and water released from the glacier was estimated at $200000 \mathrm{~m}^{3}$ (Mougin and Bernard, 1905; Vincent and others, 2010b). Owing to the debris flows, the flood carried more than $800000 \mathrm{~m}^{3}$ of sediment into the valley. The 1892 outburst flood killed 175 people in the town of Saint-Gervais-Le Fayet. In 2010, because of extensive urbanization, 3000 inhabitants were threatened. We warned the authorities in charge of public safety (Prefecture de Haute Savoie) on 13 July 2010, 5 days after the boreholes were completed. Immediate action was therefore taken and the subglacial lake was drained artificially between 25 August and 8 October 2010 using down-hole pumps. In total, $47700 \mathrm{~m}^{3}$ of water were pumped out of the glacier. Additional field SNMR measurements were carried out on 27 September 2010, before the end of the artificial drainage, in order to assess the remaining water volume in the glacier. The value found was $21000 \pm 4000 \mathrm{~m}^{3}$. The pumped volume between 25 August and 27 September 2010 was $31700 \mathrm{~m}^{3}$. The pumped volume between 27 September and 8 October 2010 was $16000 \mathrm{~m}^{3}$, leaving a residual volume of about $5000 \mathrm{~m}^{3}$ which could not be pumped and which likely remained in the glacier.

Pumping data show that half of the accumulated water was located between approximately 20 and $50 \mathrm{~m}$ and the other half between 50 and $65 \mathrm{~m}$. Comparison of pumping data with the SNMR image shows a good correspondence (Fig. 6). However, the caverns and channels in Glacier de Tête Rousse have complex shapes. For instance, pumping data (Fig. 6) show that a small water volume was pumped between 47 and $52 \mathrm{~m}$ depth. SNMR has a limited resolution and is unable to resolve these details.

Thus, pumping results are consistent with the lowerbound estimate on the subsurface water volume provided by 3-D-SNMR.

\subsection{Risk of glacier cavity collapse during artificial drainage}

An additional risk appeared during artificial drainage. The risk was that the release of water pressure within the cavity during drainage would precipitate the collapse of the cavity roof and potentially flush out the remaining water, flooding the valley below. For this purpose, numerical modelling was performed to quantify the risk of cavity failure during the artificial drainage (Gagliardini and others, 2011). It was found that the maximum tensile stress in the cavity roof was below the rupture value, indicating a low risk of collapse.

\subsection{Origin and formation of the subglacial cavity}

Although the danger was avoided, the origin of the subglacial cavity must be clarified to assess the future risk for this glacier. We discuss below some points relative to the cause of water drainage and water retention; however, no firm conclusions can be drawn.

\subsubsection{Origin of the water and drainage system}

The question of the origin of the meltwater feeding the water reservoir remains unclear. This point is important because it determines the potential annual volume of water feeding the subglacial cavity. The water coming from surface melt and rain usually flows through veins in the temperate ice of the upper part of the glacier (Fountain and others, 2005). However, even in the upper borehole, Glacier de Tête Rousse is not temperate in the first $50 \mathrm{~m}$ from the surface and it is unlikely that the meltwater penetrates ice in this region. A second possibility is that the water flows through the glacier in channels formed by crevasses. However, visual observations reveal no crevasses in the upper part of this glacier and ice flow is very low in this area, i.e. $<0.5 \mathrm{~m} \mathrm{a}^{-1}$ (Vincent and others, 2010b). A third possibility is that the percolating water could be transmitted downward into the porous firn in the highest part of the accumulation zone (upstream of borehole 17). Unfortunately, we could not drill and install thermistors in this area because of the steep slope. Thus, we cannot confirm whether this area is temperate. A fourth possibility is that the water penetrates into the interface between the side of the valley and the glacier.

These mechanisms for drainage from the surface to bedrock should be studied in detail in the future. Some future experiments are proposed in Section 5. A very simple 
calculation has been made in order to estimate the potential annual volume of water available from surface melting. Given that the melting surface area upstream of the water reservoir is 6 ha and that the observed ablation rate is $1.0 \pm 0.5 \mathrm{~m}$ w.e. $\mathrm{a}^{-1}$ in this area, the potential annual volume of water is $30000-90000 \mathrm{~m}^{3}$. However, it is very probable that a large part of this water flows on the surface and does not penetrate the glacier.

Whatever the mechanism explaining the penetration of water from surface melt and rain, this water reaches the bottom of the glacier and is trapped when it reaches the centre of the glacier. It is very likely that basal drainage is slow because no subglacial water flows from the snout of Glacier de Tête Rousse. Thus, it is probable that the flowing water does not dissipate enough heat energy to melt the ice and therefore cannot keep Röthlisberger channels open (Röthlisberger, 1972) at the base of Glacier de Tête Rousse. Consequently, water discharge in this slow system may move through linked cavities, conduits within the bed (Nye channels) or subglacial sediments (Fountain and Walder, 1998). From our data, the basal drainage system in Glacier de Tête Rousse remains uncertain and no conclusions can be drawn. In any case, given that the ice flow is very slow, basal motion cannot explain the formation of subglacial cavities.

\subsubsection{Cause of water storage}

Another question concerns the cause of water storage in this glacier. Numerous temperature measurements from deep drilling holes enable us to determine the thermal regime of this glacier. First, our measurements (Figs $4 \mathrm{c}$ and 8 ) show clearly that the tongue of the glacier is cold $\left(\sim-2{ }^{\circ} \mathrm{C}\right)$. On the other hand, in the upper part of the glacier, the ice temperature is between $-1.2^{\circ} \mathrm{C}$ and $0^{\circ} \mathrm{C}$. In this area, the basal ice is temperate in the first $10 \mathrm{~m}$ above bedrock (Fig. 8). The horizontal gradient in ice temperature measured $15 \mathrm{~m}$ below the surface, between the snout and the upper part, is probably linked to the latent heat produced by the refreezing of surface meltwater in the firn, as explained below. In the accumulation zone, given that the firn persists throughout the year, the amount of latent heat is high because it occurs over the entire summer (Pettersson and others, 2004). Conversely, in the ablation zone, the winter snow layer disappears generally at the end of July or in August. Consequently, when the tongue ice is exposed, the latent heat due to surface melting is lost through surface runoff. This effect can produce a large difference in ice temperature between accumulation and ablation zones, as already found for others polythermal glaciers (e.g. Aschwanden, 2008). The horizontal variations of ice temperature might also be caused partly by spatial variations of the heat flux within the underlying bedrock (Lüthi and Funk, 2001). In the case of Glacier de Tête Rousse, the temperature field is also influenced by the presence of the subglacial water-filled cavity. The other sources of heat within the glacier are strain heating due to ice deformation and sliding friction. However, given that the ice flow of this glacier is very low (Vincent and others, 2010b), these heat sources can be neglected. Consequently, the temperature pattern observed in Figure 4c depends mainly on the heat fluxes coming from the surface, the latent heat produced by the refreezing of surface meltwater in the firn, the basal heat flux and the heat flux between the water of the subglacial cavity at $0^{\circ} \mathrm{C}$ and the surrounding cold ice. A detailed study using numerical heat modelling is underway to assess the effects of the different components and the evolution of the thermal regime of this glacier with time. In any case, the subglacial cavity is located just upstream of the cold zone. Although the ice overburden pressure could play a role in water retention, it is not a sufficient condition because artesian outpourings occurred after the drilling of two boreholes, which revealed that the effective pressure was negative. Therefore, the thermal regime of this glacier could explain, at least in part, the storage of water within the glacier. Like Trapridge Glacier, Canada (Jarvis and Clarke, 1975; Flowers and Clarke, 2000), the cold tongue of Glacier de Tête Rousse may act as a thermal barrier to the flow of water. Therefore, the water of Glacier de Tête Rousse cannot escape along the bed and is trapped beneath the glacier.

\subsubsection{Growth of the subglacial cavity}

Owing to the accumulation of water in this area, the subglacial cavity probably expanded gradually as the basal water pressure increased. The growth of the subglacial cavity depends on different interacting processes (Roberts, 2005), i.e. flotation of the ice damming the water-filled reservoir, refreezing of the cavity roof due to the heat flux between the water of the subglacial lake and the surrounding cold ice and hydrologically driven propagation of fractures due to the water pressure (Van der Veen, 1998, 2007). Our data do not enable us to provide a more detailed explanation of the processes which led to the growth of this subglacial cavity. In any case, the water could not find a way to escape through a subglacial conduit. This is confirmed by the absence of a hydraulic outlet from the snout. According to the keeper of the mountaineering hut located $250 \mathrm{~m}$ from the snout, no visible subglacial water has escaped from the glacier over at least the last 7 years. Unlike Trapridge Glacier, which has a similar thermal regime (Flowers and Clarke, 2000), it seems that the subglacial water of Glacier de Tête Rousse does not escape through subsurface aquifers.

\section{CONCLUSIONS AND PERSPECTIVES}

The study presented here shows that the combined use of GPR and 3-D-SNMR provides effective diagnostics for the presence of a subglacial water-filled cavity in Glacier de Tête Rousse. The volume of water assessed by SNMR was estimated at $55000 \pm 10000 \mathrm{~m}^{3}$. The presence of a subglacial lake was confirmed by boreholes drilled in July 2010. Consequently, the hazard related to a potential new outburst flood was analysed urgently on the basis of the following main results. The geophysical surveys and boreholes revealed that this water was very likely contained in a single subglacial cavity. In addition, artesian outpourings occurred when the subglacial cavity was reached by two borehole drillings, indicating that the hydrostatic water pressure exceeded the ice pressure at the bottom of the cavity. On the basis of the knowledge we had at the time, we could expect a sudden release of the water contained within this glacier. We warned the authorities in charge of public safety on 13 July 2010. The consequence of a potential outburst flood was examined immediately by analogy with the 1892 event. Given that the volume of water contained in the glacier in July 2010 was similar to the volume of water contained in the glacier before the 1892 disaster, an immediate decision was made to drain the subglacial lake artificially. The lake was drained between August and October 2010 using down-hole pumps. 
As mentioned in Section 1, the tunnel drilled through the rock in 1904 has been maintained until now and was supposed to prevent water accumulation close to the bedrock of the glacier. Over the last 106 years, no water has been drained through this tunnel. The detection of a new subglacial lake in this glacier shows that this tunnel is not useful in the prevention new outburst floods.

The origin and formation processes of this subglacial lake remain unclear. Although the cavity has been emptied and the immediate danger avoided, many questions remain unresolved. Our ice temperature measurements suggest that water accumulation is due to watertight cold ice in the lower part of the glacier. The absence of subglacial water flowing from the snout provides a first indication of water accumulation within the glacier. This indicator can be useful for other studies.

Given that the cause of the water accumulation is related to the thermal regime and that the changes in ice temperature are slow, the cavity might fill again in the future. Consequently, the filling of the subglacial cavity must be carefully monitored. We suggest monitoring the water level in the cavity based on water pressure measurements by sensors set up in boreholes. The water level change can be converted to water volume change using water level and pumped discharge data obtained during the artificial drainage. However, given that the geometry of the cavity is changing due to cavity closure following reservoir drainage, the water level measurements are not sufficient. Thus, we plan to perform SNMR measurements regularly to check the water volume. Additional GPR measurements will be carried out to measure the position of the cavity roof. We suggest the use of dye tracing in the accumulation zone and in the upper part of the drainage basin to determine the origin of the meltwater that feeds the subglacial lake and the water transit speeds from the surface to the subglacial cavity. These experiments could enable us to determine the potential area that feeds the subglacial cavity and the annual available meltwater volume. For the same purpose, we suggest accurately measuring annual melting in the upper part of the glacier and in the upper drainage basin.

Finally, a thermal regime study based on numerical heat modelling is needed to investigate the long-term change in ice temperature over the last century and the possible evolution over the next decades. Such a study could help us to determine when this lake appeared.

\section{ACKNOWLEDGEMENTS}

This study was funded by the Service de Restauration des Terrains en Montagne (RTM) of Haute Savoie, France, the town of Saint-Gervais, France, and Joseph Fourier University (Pôle TUNES programme). Funding was also provided by the GlaRiskAlp Alcotra Programme. We thank P. Possenti and E. Lefèbvre for conducting the drilling operations. We are grateful to $\mathrm{H}$. Harder who revised the English of the manuscript, and M. Funk, D. Rippin and two anonymous reviewers whose comments improved the quality of the manuscript.

\section{REFERENCES}

Arcone SA, Lawson DE and Delaney AJ (1995) Short-pulse radar wavelet recovery and resolution of dielectric contrasts within englacial and basal ice of Matanuska Glacier, Alaska, USA. J. Glaciol., 41(137), 68-86
Aschwanden A (2008) Mechanics and thermodynamics of polythermal glaciers. (DSc thesis, ETH Zürich)

Barrett BE, Murray T, Clark R and Matsuoka K (2008) Distribution and character of water in a surge-type glacier revealed by multifrequency and multipolarization ground-penetrating radar. J. Geophys. Res., 113(F4), F04011 (doi: 10.1029/2007JF000972)

Björnsson H (1974) Explanation of jökulhlaups from Grímsvötn, Vatnajökull, Iceland. Jökull, 24, 1-26

Björnsson H (1992) Jökulhlaups in Iceland: prediction, characteristics and simulation. Ann. Glaciol., 16, 95-106

Björnsson H (2003) Subglacial lakes and jökulhlaups in Iceland. Global Planet. Change, 35(3-4), 255-271 (doi: 10.1016/ S0921-8181(02)00130-3)

Björnsson H (2010) Understanding jökulhlaups: from tale to theory. J. Glaciol., 56(200), 1002-1010

Björnsson $\mathrm{H}$ and 6 others (1996) The thermal regime of sub-polar glaciers mapped by multi-frequency radio-echo sounding. J. Glaciol., 42(140), 23-32

Boon S and Sharp M (2003) The role of hydrologically-driven ice fracture in drainage system evolution on an Arctic glacier. Geophys. Res. Lett., 30(18), 1916 (doi: 10.1029/ 2003GL018034)

Boucher M, Girard J-F, Legchenko A, Baltassat J-M and Dörfliger N (2006) Using 2D inversion of magnetic resonance soundings to locate a water-filled karst conduit. J. Hydrol., 330(3-4), 413-421 (doi: 10.1016/j.jhydrol.2006.03.034)

Callaghan PT, Dykstra R, Eccles CD, Haskell TG and Seymour JD (1999) A nuclear magnetic resonance study of Antarctic sea ice brine diffusivity. Cold Reg. Sci. Technol., 29(2), 153-171

Clague JJ and Mathews WH (1973) The magnitude of jökulhlaups. J. Glaciol., 12(66), 501-504

Clarke GKC (1982) Glacier outburst floods from 'Hazard Lake', Yukon Territory, and the problem of flood magnitude prediction. J. Glaciol., 28(98), 3-21

Deparis J and Garambois S (2009) On the use of dispersive APVO GPR curves for thin-bed properties estimation: theory and application to fracture characterization. Geophysics, 74(1), J1-J12 (doi: 10.1190/1.3008545)

Flowers GE and Clarke GKC (2000) An integrated modelling approach to understanding subglacial hydraulic release events. Ann. Glaciol., 31, 222-228 (doi: 10.3189/ 172756400781820471)

Fountain AG and Walder JS (1998) Water flow through temperate glaciers. Rev. Geophys., 36(3), 299-328 (doi: 10.1029/ 97RG03579)

Fountain AG, Jacobel RW, Schlichting R and Jansson P (2005) Fractures as the main pathways of water flow in temperate glaciers. Nature, 433(7026), 618-621 (doi: 10.1038/ nature03296)

Gagliardini O, Gillet-Chaulet F, Durand G, Vincent C and Duval P (2011) Estimating the risk of glacier cavity collapse during artificial drainage: the case of Tête Rousse Glacier. Geophys. Res. Lett., 38(10), L10505 (doi: 10.1029/2011GL047536)

Girard J-F, Boucher M, Legchenko A and Baltassat J-M (2007) 2D magnetic resonance tomography applied to karstic conduit imaging. J. Appl. Geophys., 63(3-4), 103-116 (doi: 10.1016/ j.jappgeo.2007.08.001)

Haeberli W (1983) Frequency and characteristics of glacier floods in the Swiss Alps. Ann. Glaciol., 4, 85-90

Haeberli W, Alean JC, Müller P and Funk M (1989) Assessing risks from glacier hazards in high mountain regions: some experiences in the Swiss Alps. Ann. Glaciol., 13, 96-102

Haeberli W, Kääb A, Vonder Mühll D and Teysseire P (2001) Prevention of outburst floods from periglacial lakes at Grubengletscher, Valais, Swiss Alps. J. Glaciol., 47(156), 111-122 (doi: 10.3189/172756501781832575)

Haeberli W and 7 others (2002) A surge-type movement at Ghiacciaio del Belvedere and a developing slope instability in the east face of Monte Rosa, Macugnaga, Italian Alps. Nor. Geogr. Tidsskr., 56(2), 104-111 
Hertrich M (2008) Imaging of groundwater with nuclear magnetic resonance. Progr. Nucl. Magn. Reson. Spectrosc., 53(4), 227-248 (doi: 10.1016/j.pnmrs.2008.01.002)

Hertrich M, Green AG, Braun M and Yaramanci U (2009) Highresolution surface NMR tomography of shallow aquifers based on multioffset measurements. Geophysics, 74(6), G47-G59 (doi: 10.1190/1.3258342)

Irvine-Fynn TDL, Moorman BJ, Williams JLM and Walter FSA (2006) Seasonal changes in ground-penetrating radar signature observed at a polythermal glacier, Bylot Island, Canada. Earth Surf. Process. Landf., 31(7), 892-909 (doi: 10.1002/esp.1299)

Jarvis GT and Clarke GKC (1975) The thermal regime of Trapridge Glacier and its relevance to glacier surging. J. Glaciol., 14(71), 235-250

Kleinberg RL and Griffin DD (2005) NMR measurements of permafrost: unfrozen water assay, pore-scale distribution of ice, and hydraulic permeability of sediments. Cold Reg. Sci. Technol., 42(1), 63-77 (doi: 10.1016/j.coldregions.2004.12.002)

Legchenko AV and Shushakov OA (1998) Inversion of surface NMR data. Geophysics, 63(1), 75-84 (doi: 10.1190/1.1444329)

Legchenko A and Valla P (2002) A review of the basic principles for proton magnetic resonance sounding measurements. J. Appl. Geophys., 50(1-2), 3-19 (doi: 10.1016/S0926-9851(02)00127-1)

Legchenko AV, Beauce A, Guillen A, Valla P and Bernard J (1997) Natural variations in the magnetic resonance signal used in PMR groundwater prospecting from the surface. Eur. J. Environ. Eng. Geophys., 2, 173-190

Legchenko A, Baltassat J-M, Bobachev A, Martin C, Robain H and Vouillamoz J-M (2004) Magnetic resonance sounding applied to aquifer characterization. Ground Water, 42(3), 363-373 (doi: 10.1111/j.1745-6584.2004.tb02684.x)

Legchenko A, Ezersky M, Camerlynck C, Al-Zoubi A, Chalikakis K and Girard J-F (2008) Locating water-filled karst caverns and estimating their volume using magnetic resonance soundings. Geophysics, 73(5), G51-F61 (doi: 10.1190/1.2958007)

Legchenko A and 6 others (2011) Three-dimensional magnetic resonance imaging for groundwater. New J. Phys., 13, 025022 (doi: 10.1088/1367-2630/13/2/025022)

Lüthi MP and Funk M (2001) Modelling heat flow in a cold, highaltitude glacier: interpretation of measurements from Colle Gnifetti, Swiss Alps. J. Glaciol., 47(157), 314-324 (doi: 10.3189/ 172756501781832223)

Mathews WH (1964) Discharge of a glacial stream. IASH Publ. 63 (General Assembly of Berkeley 1963 - Surface Water), 290-300

Moran ML, Greenfield RJ, Arcone SA and Delaney AJ (2000) Delineation of a complexly dipping temperate glacier bed using short-pulse radar arrays. J. Glaciol., 46(153), 274-286 (doi: 10.3189/172756500781832882)

Morozov VA (1966) On the solution of functional equations by the method of regularization. Dokl. Akad. Nauk SSSR, 7, 414-417

Mortara G and Mercalli L (2002) Il lago epiglaciale 'Effimero' sul ghiacciaio del Belvedere, Macugnaga, Monte Rosa. Nimbus, 23-24, 10-17

Mougin P and Bernard C (1905) Études exécutées au glacier de Tête Rousse. In Vallot J ed. Annales de l'Observatoire météorologique, physique et glaciaire du Mont Blanc (altitude 4,358 mètres), Tome VI. G. Steinheil, Paris

Müller-Petke M, Dlugosch R and Yaramanci U (2011) Evaluation of surface nuclear magnetic resonance-estimated subsurface water content. New J. Phys., 13, 095002 (doi: 10.1088/1367-2630/13/ 9/095002)

Murray T, Gooch DL and Stuart GW (1997) Structures within the surge front at Bakaninbreen, Svalbard, using ground-penetrating radar. Ann. Glaciol., 24, 122-129

Murray T, Stuart GW, Fry M, Gamble NH and Crabtree MD (2000) Englacial water distribution in a temperate glacier from surface and borehole radar velocity analysis. J. Glaciol., 46(154), 389-398 (doi: 10.3189/172756500781833188)

Pettersson R, Jansson P and Blatter H (2004) Spatial variability in water content at the cold-temperate transition surface of the polythermal Storglaciären, Sweden. J. Geophys. Res., 109(F2), F02009 (doi: 10.1029/2003JF000110)

Roberts MJ (2005) Jökulhlaups: a reassessment of floodwater flow through glaciers. Rev. Geophys., 43(RG1), RG1002 (doi: 10.1029/2003RG000147)

Röthlisberger H (1972) Water pressure in intra- and subglacial channels. J. Glaciol., 11(62), 177-203

Schirov M, Legchenko A and Creer G (1991) A new direct noninvasive groundwater detection technology for Australia. Expl. Geophys., 22(2), 333-338 (doi: 10.1071/EG991333)

Slichter CP (1990) Principles of magnetic resonance, 3rd edn. Springer-Verlag, Berlin

Sturm M and Benson CS (1985) A history of jökulhlaups from Strandline Lake, Alaska, USA. J. Glaciol., 31(109), 272-280

Sugiyama S, Bauder A, Huss M, Riesen P and Funk M (2008) Triggering and drainage mechanisms of the 2004 glacierdammed lake outburst in Gornergletscher, Switzerland. J. Geophys. Res., 113(F4), F04019 (doi: 10.1029/2007JF000920)

Tarantola A (2005) Inverse problem theory and methods for model parameter estimation. Society for Industrial and Applied Mathematics (SIAM), Philadelphia, PA

Tikhonov AN and Arsenin VY (1977) Solutions of ill-posed problems. V.H. Winston, Washington, DC

Vallon M (1989) Evolution, water balance, potential hazards, and control of a pro-glacial lake in the French Alps. Ann. Glaciol., 13, 273-278

Van der Veen CJ (1998) Fracture mechanics approach to penetration of surface crevasses on glaciers. Cold Reg. Sci. Technol., 27(1), 31-47

Van der Veen CJ (2007) Fracture propagation as means of rapidly transferring surface meltwater to the base of glaciers. Geophys. Res. Lett., 34(1), L01501 (doi: 10.1029/2006GL028385)

Vincent C, Auclair S and Le Meur E (2010a) Outburst flood hazard for glacier-dammed Lac de Rochemelon, France. J. Glaciol., 56(195), 91-100 (doi: 10.3189/002214310791190857)

Vincent C, Garambois S, Thibert E, Lefèbvre E, Le Meur E and Six D (2010b) Origin of the outburst flood from Glacier de Tête Rousse in 1892 (Mont Blanc area, France). J. Glaciol., 56(198), 688-698 (doi: 10.3189/002214310793146188)

Walder JS and Driedger CL (1995) Frequent outburst floods from South Tahoma Glacier, Mount Rainier, USA: relation to debris flows, meteorological origin and implications for subglacial hydrology. J. Glaciol., 41(137), 1-10

Werder MA, Bauder A, Funk M and Keusen H-R (2010) Hazard assessment investigations in connection with the formation of a lake on the tongue of Unterer Grindelwaldgletscher, Bernese Alps, Switzerland. Natur. Hazards Earth Syst. Sci. (NHESS), 10(2), 227-237 (doi: 10.5194/nhess-10-227-2010)

\section{APPENDIX: SUMMARY OF THE MAGNETIC RESONANCE SOUNDING METHOD}

The magnetic resonance sounding (MRS) method is based on the nuclear magnetic resonance (NMR) phenomenon (Slichter, 1990; Hertrich, 2008) in the Earth's magnetic field. MRS is a selective method specifically sensitive to groundwater. Direct detection of subsurface water is the main advantage of MRS compared with other geophysical tools used for hydrogeological investigations. The frequency of the MRS signal is equal to the Larmor frequency of the protons in the geomagnetic field $f_{0}=\omega_{0} / 2 \pi=\gamma B_{0} / 2 \pi$, with $B_{0}$ being the geomagnetic field and $\gamma$ the gyromagnetic ratio for protons. Depending on the global geographic location of the investigated area, the Larmor frequency varies between 800 and $2800 \mathrm{~Hz}$. In the French Alps, the geomagnetic field is about $47066 \mathrm{nT}$ and the corresponding Larmor frequency is about $2005 \mathrm{~Hz}$. 
An MRS field set-up consists of a coincident transmitting/ receiving loop laid out on the ground, usually in a square, with side lengths between 20 and $150 \mathrm{~m}$. The loop is energized by a pulse of alternating current $i(t)=I_{0} \cos (\omega t)$ with a frequency $\omega \approx \omega_{0}$. Measurements of the magnetic resonance signal are made with the same loop after the pulse has terminated. One sounding is composed of MRS signals measured for different values of the pulse moment $q=I_{0} \tau$, with $I_{0}$ and $\tau$ the amplitude and duration of the pulse, respectively. The induced signal in the receiving loop is (Legchenko and others, 2004)

$$
E_{0}(q)=\omega_{0} M_{0} I_{0}^{-1} \int_{V} B_{1} \mathrm{e}^{\mathrm{j} \varphi_{0}(r)} \sin \left(\gamma I_{0}^{-1} B_{1} q / 2\right) w(r) \mathrm{d} V
$$

where $M_{0}$ is the nuclear magnetization for the protons, $B_{1}(\mathbf{r}, \rho(V), \alpha)$ the component of the transmitting magnetic field perpendicular to the geomagnetic field, $\alpha$ the geomagnetic field inclination, $\rho(\mathbf{r})$ the subsurface resistivity, $0 \leq w(\mathbf{r}) \leq \mathbf{1}$ the water content and $r=r(x, y, z)$ the coordinate vector. By solving Eqn (A1), we obtain the subsurface water distribution $w(\mathbf{r})$.

The 3-D implementation uses overlapping Tx/Rx loops. The 3-D imaging consists of measuring the surface NMR (SNMR) signal independently in each loop while varying the pulse moment. All individual soundings are incorporated into a dataset for 3-D inversion. For interpretation, the field measurement equation (Eqn (A1)) can be approximated by a matrix equation (Legchenko and Shushakov, 1998)

$$
\mathbf{A w}=\mathbf{e} \text {, }
$$

where $\mathbf{A}=\left[\widetilde{\mathrm{a}}_{i, j}\right]$ is a rectangular matrix of

$$
\begin{aligned}
I \times J(i & =1,2, \ldots, I ; j=1,2, \ldots, J ; I=K \times L ; J=J_{x} \times J_{y} \times J_{z} ; \\
K & =\sum_{l=1}^{L} K_{i} ; I=1,2, \ldots, L \\
j_{x} & \left.=1,2, \ldots, J_{x}, j_{y}=1,2, \ldots, J_{y} j_{z}=1,2 ., . . J_{z}\right),
\end{aligned}
$$

$K_{\text {I }}$ the number of pulse moments for a loop $I, L$ the number of measuring loops and $J_{x}, J_{y}, J_{z}$ the number of cells in the $x$, $y$ and $z$ directions, respectively.

In Eqn (A2), the elements of matrix $\mathbf{A}$ represent the amplitude of the magnetic resonance signal generated by water in corresponding cells (assuming a 100\% water content in each cell) and computed using Eqn (A1). The set of experimental data is $\mathbf{e}=\left(\widetilde{e}_{1}, \widetilde{e}_{2}, . ., \widetilde{e}_{i}, . ., \widetilde{e}_{l}\right)^{T}$, the water content in the corresponding cell is $\mathbf{w}=\left(w_{1}, w_{2}, . ., w_{j}, . ., w_{J}\right)^{T}$ and $T$ denotes the transposition. For simplicity, we assume that the cell size is constant throughout the investigated volume.

Inversion of the 3-D-SNMR data is ill-posed. Different methods suitable for resolution of ill-posed inverse problems can be found in the literature (Tarantola, 2005). For our study the inversion was conducted according to Tikhonov's regularization method (Tikhonov and Arsenin, 1977).

Knowledge of the water content makes it possible to estimate the total amount of water in the subsurface as

$$
V_{\mathrm{MRS}}=\int_{V} w(r) \mathrm{d} V \text {. }
$$

